\section{Retail Florists Use Novel Sales Approaches during the COVID-19 Pandemic}

\author{
Coleman L. Etheredge ${ }^{1}$ and James DelPrince ${ }^{2}$
}

ADDITIONAL INDEX WORDS. coronavirus, floriculture, horticulture, marketing

Summary. Retail florists in the United States were surveyed from Oct. to Nov. 2020 to document business practices and innovative approaches to marketing, designing, and delivering flowers during Mar. to Sept. 2020 of the coronavirus disease (COVID-19) pandemic. Slightly less than half of the responding florists $\mathbf{( 4 5 . 0 \% )}$ closed operations for an average of 31 to 60 days $(15.6 \%)$. City or county COVID-19 restrictions caused 34\% to close their storefronts to customers. Nearly all offered no-contact delivery service. Approximately onethird of these florists used social media marketing consisting of still images and video posts, and a similar number offered no-contact shopping options. Twothirds of the florists made no changes to the way they designed flowers $(60.6 \%)$. Event-oriented stores reorganized their business models and sought daily work to replace postponed or canceled wedding orders. Three-fourths of the florists who terminated employees because of shutdowns hired or planned to rehire all terminated employees.

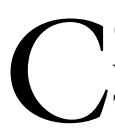
OVID-19 has posed a worldwide threat to public health. The World Health Organization declared the coronavirus outbreak a worldwide pandemic in Mar. 2020 (World Health Organization, 2020). In addition to concerns about the health of family, friends, and loved ones and healthcare collapse, fear quickly developed because of the unknown ways the virus could affect business (Mertens et al., 2020).

The COVID-19 pandemic and government efforts to halt the spread of coronavirus had serious consequences for small and medium businesses, but less so for many large companies and multinational corporations (Turner and Akinremi, 2020). According to the U.S. Small Business Administration (2020), floral shops, greenhouse growers, florist suppliers, and floral wholesaler merchants qualify as a small business if they maintain 500 or fewer employees. The majority $(86.8 \%)$ of retail flower

Received for publication 22 July 2021. Accepted for publication 22 Sept. 2021.

Published online 9 November 2021.

${ }^{1}$ Department of Plant and Soil Sciences, Mississippi State University, Starkville, MS 39759

${ }^{2}$ Coastal Research and Extension Center, Mississippi State University, Biloxi, MS 39532

C.L.E. is the corresponding author. E-mail: cle248@msstate.edu.

This is an open access article distributed under the CC BY-NC-ND license (https://creativecommons. org/licenses/by-nc-nd/4.0/).

https://doi.org/10.21273/HORTTECH04920-21 shop owners have zero to four employees on staff (Business Brokerage Press, 2020).

In a study of more than 5800 U.S.-based small businesses, $43 \%$ temporarily closed because of COVID-19 (Bartik et al., 2020). These closures were predominantly caused by the lower demand for goods and services and employee health concerns. Pandemic duration estimates affected owners' expectations for keeping their businesses open. By 1 Apr. 2020, 72\% of businesses estimating 1 month of crisis duration expected to be open by December but for those estimating 4 crisis months, less than half expected to be open by the end of the year (Bartik et al., 2020).

Easter was the first floral holiday that florists experienced during the crisis. In a post Easter survey, Society of American Florists retail members reported a 55\% decrease in 2020 Easter/ Passover sales as compared with 2019 $29 \%$ reported an increase in sales, and $6 \%$ reported that their sales remained the same (Westbrook, 2020a). In the same survey, only $31 \%$ of the retail members predicted a Mother's Day sales increase while $48 \%$ felt sales would decrease from the previous year (Westbrook, 2020a).

In a post-Mother's Day survey, $70 \%$ of respondents' sales increased over the previous year, $24 \%$ decreased and $6 \%$ remained the same. During that holiday, respondents' staffing was at $75 \%$ of their pre-COVID-19 levels (Westbrook, 2020b). In Sept. 2020, 6 months into the pandemic, florists had weathered the usually slower summer months and felt at least somewhat confident that their businesses would endure the pandemic (Westbrook, 2020c).

There are no floral industry data from the 1918 pandemic (Spanish Flu) that could help current owners make business decisions, despite the predictions of a pandemic return; however, records from that time provide interesting anecdotal insights (Solly, 2020; Taubenberger and Morens, 2006). Studies examining previous pandemic effects on business and, in particular, the effects on small businesses are extremely limited (Turner and Akinremi, 2020). The number of hours worked decreased sharply because of illness and fear of infection. Like the COVID-19 pandemic, the Spanish Flu resulted in lockdowns established by local governments that led to cancelations of leisure activities such as travel and sporting events and resulted in local retail sales reductions. Because of government lockdowns to contain the spread of infection, global trade and supply chains became interrupted, further disrupting businesses. Labor shortages and long-term reductions in productivity were a result of the 1918 pandemic, which resulted in 40 million people losing their lives worldwide (Turner and Akinremi, 2020).

Research findings of COVID-19 effects on floral business operations are emerging. A retail florist study performed in Brazil reported fewer daily customers, illustrating a $45.3 \%$ average decrease in transaction value. Shops were closed for $\approx 3$ weeks, and restrictions to hours and the number of patrons allowed in stores were implemented after reopening (Anacleto et al., 2020). Brazil reported 12.5 million cases and 313,866 deaths (Allen et al., 2021a); however, these numbers were superseded by the United States, with 30.3 million cases and 549,552 deaths (Allen et al., 2021b) as of 30 Mar. 2021.

At the onset of the pandemic, reports showed that flowers were dumped by growers and cooperative markets worldwide due to disruption in the floral supply chain, resulting from temporary closures of retail and wholesale flower shops (Faux et al., 2020; Kakissisk, 2020). These closures 
caused ripple effects throughout the floriculture industry. Because of the low demand, floral transporters had to cut the number of weekly shipments from growers to wholesalers to remain economically viable (Wright, 2020).

The main objective of this study was to investigate the effects of COVID-19 on innovative marketing approaches by U.S. retail florists during the COVID-19 pandemic. Secondary objectives of the study were to find design, delivery, and sales approaches these florists used to remain economically viable.

\section{Materials and methods}

SAmple. A contact list of 1974 retail florists was used. The contact list was initially assembled in 2019 for a study investigating florist willingness to compost floral waste (Etheredge and Waliczek, 2020). The list was assembled by conducting a web-based search for retail florists in each of the 50 states. Using a "florist finder" website, a county-by-county search within each state was conducted to ensure all regions were represented and not just those around highly populated areas. E-mails were collected by visiting individual retail florist shop websites and gathering the e-mail information provided. An initial list of 3397 retail flower shops was reduced to 1974 because some floral shops did not list their e-mail addresses on their shop website and because of inactive e-mail addresses.

The online survey (Institutional Review Board protocol 20-215; May 2020) was e-mailed to 1974 retail florists within all 50 states and Washington, DC, over the span of 2 months (Oct.-Nov. 2020). The number of shops per state varied because of population differences; however, efforts were made to contact as many florists within each state as possible. Florists were sent a standardized e-mail explaining the purpose of the study and an embedded hyperlink redirecting willing respondents to the survey. The survey was anonymous. Each shop on the mailing list was contacted only once to avoid data duplication.

Questions developed for this study were intentionally exploratory and left open-ended to gather a large variety of responses. Questions were reviewed for validity by horticultural researchers experienced in qualitative survey construction and administration. The survey instrument consisted of 10 questions within four different sections. The first section included two questions pertaining to the respondent's closure and safety guidelines enacted because of COVID-19. Questions included "Did your retail floral store close at any time between 1 Mar. 2020 and 1 Sept. 2020 due to the COVID-19 pandemic?" and "Did your city or county enforce any guidelines that your business had to adhere to? If yes, please list the guidelines."

The second section consisted of four questions pertaining to innovative approaches respondents used for marketing, designing, and delivering flowers during the COVID-19 pandemic. Questions included "Did you take any innovative approaches for marketing of your business during the COVID-19 pandemic? If yes, please list." and "Did you take any innovative approaches to designing of flowers and floral goods during the COVID-19 pandemic? If yes, please list."

The third section consisted of two questions pertaining to the financial status of the retail flower shop during the COVID-19 pandemic. Questions included "Did you have to terminate any employees due to the COVID-19 pandemic? If so, will all or some of these employees be rehired?" and "Did your flower shop undergo financial losses during the COVID-19 pandemic? If so, what is the estimated net loss to the flower shop?"

Answers for the first three sections included "yes" and "no" responses as well as space to allow respondents to answer open-ended questions. Openended responses were reviewed by researchers and grouped into overall themes based on responses given by individual respondents to each question. The final section of the survey consisted of two demographic questions related to the state location of the flower shops and how they would describe the regional location of their shop ("urban," "suburban," or "rural").

Data analysis. Responses were categorized into themes identified through the exploration of the data using method collection techniques used in a previous study (McFarland et al., 2018). Text from the responses was not categorized by question; instead, it was coded as a unit whereby responses could fit into as many categories as mentioned within the response (McFarland et al., 2018). After responses were coded, data were entered into IBM SPSS Statistics (version 26; IBM Corp., Armonk, NY). Descriptive statistics were used to discern the frequency with which participants mentioned each theme. Cross tabulations and Pearson's chi-square test were used to compare survey responses and identify significant differences.

\section{Results and discussion}

SuRvey RESPONSE. Of the 1974 e-mails sent to retail florists, 318 (16\%) were returned as undeliverable, resulting in a total of 1656 delivered surveys. The surveys may have been undeliverable because of typographical errors, full mailboxes, shops that left associated wire service memberships or membership in arrears, or shops that had gone out of business.

The survey was successfully completed by 109 respondents from 37 states who identified themselves as the owner or final decision-maker of the retail flower shop $(6.58 \%$ response rate; $100 \%$ completion rate). The response rate was in line with recent Society of American Florists studies' response rates of $6 \%$ to $8 \%$ (Westbrook, 2020a, 2020b, 2020c). Because of the relatively small sample size and the fact that the sample included only those who volunteered to participate in the survey instead of a randomly sampled population, the results are not necessarily generalizable beyond this study. Shop locations were evenly distributed among rural $(23 \%)$, suburban $(35 \%)$, and urban (42\%) locations.

TIME SPENT SHUT DOWN AND SAFETY GUIDELINES ENACTED BY RETAIL FLORISTS BECAUSE OF COVID-19. Of the retail florists who responded, 49 (45.0\%) had to cease operations at some point between 1 Mar. and I Sept.; this was just $6 \%$ higher than the national average (Bartik et al., 2020). The average duration of time spent closed reported by respondents was between 31 and $60 \mathrm{~d}$ [17 shops (15.6\%)]. A total of five shops $(4.6 \%)$ reported closing for 61 to $90 \mathrm{~d}$ (Table 1 ).

Some respondents [20 (18.3\%)] replied that they did not have city or county guidelines for closures, masking, or social distancing. One-third followed governmental guidelines to close their storefronts, allowed Internet and phone orders, and/or allowed curbside 
pick-up of merchandise. The level of guideline enforcement varied by location. Two (1.8\%) shops chose to ignore city/county COVID-19 restrictions. Masks and social distancing rules were enacted at 31 shops $(28.4 \%)$ that kept their storefronts open.

INNOVATIVE APPROACHES TO MARKETING RETAIL FLORIST BUSINESSES DURING THE COVID-19 PANDEMIC. Retail florists were creative when maintaining their product and service availability to the public. Many florists enacted multiple innovative approaches when marketing their business during the COVID-19 pandemic. The most common response given by participants regarding how they marketed their business was through social media (Instagram; Facebook, Menlo Park, CA) [38 respondents $(34.9 \%)]$, to contact potential buyers as well as illustrating touchless delivery and socially distanced shopping. They posted floral arrangement still images and video floral cooler walk throughs. Constant updating of shop websites resulted in posts featuring available gifts and floral stock. Some shops emphasized gifts on their websites. One shop provided enclosure cards that had "You are loved" written on them with arrangements marketed toward brightening a recipient's day and mood. Several shops indicated paying for advertisements both online and through television and newspapers in an effort to promote their shops more aggressively than using just free social media platforms (Table 1). To reduce the spread of COVID-19, some florists [34 (31.1\%)] promoted contact-free shopping options such as curbside pick-up service, particularly for spring holidays.

INNOVATIVE APPROACHES TO DESIGNING FLOWERS AND FLORAL GOODS DURING THE COVID-19 PANDEMIC. When asked if any innovative approaches to designing flowers and floral goods were taken, the majority of respondents stated they made no changes to how they designed and that they followed regular routines (Table 1). Shops that self-identified as wedding and event-oriented mentioned reorganizing their business models and sought daily work such as birthday and anniversary arrangements delivered to specified locations. Not all retail florists specialize in wedding flowers, but they design and sell them
Table 1. Florists' responses to survey questions regarding novel sales approaches during the COVID-19 pandemic.

\begin{tabular}{|c|c|c|}
\hline \multirow[b]{2}{*}{ Floral business questions and responses } & \multicolumn{2}{|c|}{ Respondents } \\
\hline & (no.) & $(\%)$ \\
\hline \multicolumn{3}{|c|}{$\begin{array}{l}\text { Did your retail floral store close at any time between } 1 \text { Mar. } 2020 \text { and } 1 \text { Sept. } \\
2020 \text { due to the COVID-19 pandemic? If so, for how long? }\end{array}$} \\
\hline No & 60 & 55.0 \\
\hline Yes & 49 & 45.0 \\
\hline $1-7 \mathrm{~d}$ & 5 & 4.6 \\
\hline $8-14 \mathrm{~d}$ & 3 & 2.8 \\
\hline $15-30 \mathrm{~d}$ & 1 & 0.9 \\
\hline $31-60 \mathrm{~d}$ & 17 & 15.6 \\
\hline $61-90 \mathrm{~d}$ & 5 & 4.6 \\
\hline Said yes days closed not specified & 18 & 16.5 \\
\hline
\end{tabular}

Did your city or county enforce any guidelines that your business had to adhere to? If yes, please list the guidelines.

No

Closed storefront, phone and Internet orders only, curbside pick-up

Store opened with masks, social distancing, and sanitation

Followed the government-issued gradual phase opening protocol

Shop chose to ignore the government-issued protocol

Completely closed

\begin{tabular}{rr}
20 & 18.3 \\
37 & 33.9 \\
31 & 28.4 \\
8 & 7.3 \\
2 & 1.8 \\
11 & 10.1 \\
\hline
\end{tabular}

Did you take any innovative approaches for marketing of your business during the COVID-19 pandemic? If yes, please list.

\begin{tabular}{lrr}
\hline No & 28 & 25.7 \\
Increased social media presence & 38 & 34.9 \\
Kept website updated & 12 & 11.0 \\
Shipped do-it-yourself (DIY) kits & 8 & 7.3 \\
Offered discounts and/or offered flower promotions & 12 & 11.0 \\
Partnered with another business & 4 & 3.7 \\
Promoted contact-free transactions/sterile conditions & 35 & 32.1 \\
Paid for online advertisements & 4 & 3.7 \\
Paid for TV/newspaper advertisements & 3 & 2.8 \\
Promoted nonfloral products & 3 & 2.8 \\
Yes but no explanation given & 7 & 6.4 \\
\hline
\end{tabular}

Did you take any innovative approaches to designing of flowers and floral goods during the COVID-19 pandemic! If yes, please list.

No

Focused on designs with lower price points

$4 \quad 3.7$

Bought more local flowers

Pushed more designer choice designs/premade designs

Made novelty quarantine designs

Streamlined website to have fewer items

Altered/scaled-down designs because of flower supply chain issues $\quad \begin{array}{lll}10 & 9.2\end{array}$

Offered DIY designs

Created more dried flower designs

Video conferences with customers to discuss designs

Removed ribbon from design to keep vases sterile

Added more keepsake items to designs

Designed with fruit more often

$1 \quad 0.9$

98.3

$7 \quad 6.4$

$3 \quad 2.8$

33.2

$3 \quad 2.8$

$1 \quad 0.9$

10.9

$2 \quad 1.8$

$1 \quad 0.9$

Did you take any innovative approaches to delivering of flowers and floral goods during the COVID-19 pandemic? If yes, please list.

\begin{tabular}{lrr}
\hline No & 11 & 10.1 \\
Enacted no-contact delivery guidelines & 92 & 84.4 \\
Called/texted customer at the time of delivery & 31 & 28.4 \\
Went from multiple delivery routes to one route per day & 1 & 0.9 \\
Contact delivery with masks & 6 & 5.5 \\
\hline
\end{tabular}

(Continued on next page) 
Table 1. (Continued)

\begin{tabular}{lrr}
\hline & \multicolumn{2}{c}{ Respondents } \\
\cline { 2 - 4 } Floral business questions and responses & (no.) & (\%) \\
\hline Added more delivery drivers & 1 & 0.9 \\
\hline Did you offer any new or different merchandise for sale during the COVID-19 \\
$\quad$ pandemic? If yes, please list. & 73 & 67.0 \\
\hline No & 9 & 8.3 \\
DIY projects/family activity & 3 & 2.8 \\
Limited number of products in store & 4 & 3.7 \\
Moved more product in the shop onto the website & 4 & 3.7 \\
Sold more plants & 11 & 10.1 \\
Hand sanitizers/masks & 3 & 2.8 \\
Self-care/bath and body & 4 & 3.7 \\
Gourmet foods/chocolates/drink mixers & & \\
\hline
\end{tabular}

Did you have to terminate any employees due to the COVID-19 pandemic? If so, will all or some of these employees be rehired?

\begin{tabular}{lrr}
\hline No & 61 & 56.0 \\
Yes & 48 & 44.0 \\
Yes, will hire/have hired back all & 26 & 23.9 \\
Yes, will hire/have hired back partial & 9 & 8.3 \\
May rehire but not sure & 3 & 2.8 \\
No, will not hire back & 3 & 2.8 \\
Employees chose not to return because of fear of COVID & 6 & 5.5 \\
Employees cannot return because of responsibilities to children & 4 & 3.7 \\
Employees will not return because they are receiving more income & 3 & 2.8 \\
$\quad$ from unemployment benefits & & \\
Quit, no reason given & 2 & 1.8 \\
\hline Did your flower shop undergo financial losses during the COVID-19 pandemic? \\
$\quad$ If so, what is the estimated net loss to the flower shop? \\
No & 30 & 27.5 \\
Had an increase in sales & 4 & 3.7 \\
Yes, not sure how much & 30 & 27.5 \\
Yes, less than $\$ 5,000$ & 1 & 0.9 \\
Yes, \$5,001-\$10,000 & 8 & 7.3 \\
Yes, \$10,001-\$50,000 & 14 & 12.8 \\
Yes, \$50,001-\$100,000 & 5 & 4.6 \\
Yes, \$100.001-\$200,000 & 7 & 6.4 \\
Yes, $>200,001$ & 10 & 9.2 \\
\hline
\end{tabular}

as part of their product line. One shop owner altered the shop's website by adding a la carte wedding floral designs so that brides could place a simple order, thus reducing consultation labor and physical contact.

Some shops noted offering less expensive flowers such as carnations (Dianthus caryophyllus) and chrysanthemums (Chrysanthemum sp.) (U.S. Department of Agriculture, 2021) to keep prices low (Table 1). Marketing cash-and-carry bouquets and arrangements at affordable price points and even reorganizing websites to emphasize styles and price points rather than specific designs were also performed to keep costs down (Table 1). Others mentioned using "standard flowers" in unusual ways because premium and unusual materials were not available through their suppliers [10 respondents (9.2\%)]. "Designer choice" arrangements [9 respondents $(8.3 \%)$ ] helped stores to sell existing inventory during the availability interruptions of many flower species. This had a positive effect for domestic growers because florists sought local sources for perishable flowers and cut foliage. Supply pressure for Mother's Day flowers caused some florists to seek sources beyond their local wholesaler and turned to direct purchases from Central American farms with import contacts in Miami, FL.

Novelty floral designs were advertised by some retailers [7 respondents
(6.4\%)]. Several shops marketed "quarantine" arrangements that used a martini glass as the container, whereas others stated they added toilet tissue to their floral designs, which was a nod to the shortage (Table 1). Another florist created fresh arrangements featuring a "stress ball." Some shops stretched the scarce perishable components of their arrangements by offering dried floral designs and incorporating dried flowers, decorative wire accents, and other items as creative accessories. Because of flower scarcities, one shop began to design with more fruits. Shops that did not normally carry many houseplants found a new outlet in the sales of individual pots and dish gardens. When necessary, one shop mentioned switching orders to green and blooming plants when cut flowers were in short supply (Table 1).

In the hard goods sector, several florists limited new supply purchases while using existing inventory. This included using the existing inventory from displays and storage for daily work. In turn, websites were updated more often and streamlined to reflect more limited design styles and inventory. To maintain sterile conditions, one shop removed ribbon from vase design work, whereas other shops mentioned adding more keepsake items to their designs (Table 1 ).

Store owners found ways to increase productivity with assembly line work. One shop adjusted design recipes to accommodate entire bunches of flowers, thereby removing the necessity to count flower stems and saving labor during busy spring holidays. Design staff members were spaced further apart in the building, and temporarily unnecessary showroom space was repurposed for design production. Staff members were organized into shifts, creating employee pods to decrease the chance of exposures. Video conferencing was used to discuss designs with customers (Table l).

INNOVATIVE APPROACHES TO DELIVERING FLOWERS. Nearly all of the responding florists [92 (84.4\%)] enacted no-contact delivery guidelines. Avoiding contact with floral gift recipients can lead to security issues with flowers being stolen. Many florists used a system of dropping flowers at the front door and calling or texting the customer to make them aware they had a flower delivery [31 respondents 
$(28.4 \%)]$. Several florists took a digital image of the floral gift on the steps of the recipient's home as proof of delivery. Several florists [6 (5.5\%)] kept contact deliveries but required their employees to wear a mask while making deliveries. Some shops furloughed employees for varying amounts of time while operating the entire shop with just one or two people in many cases, thus necessitating those remaining employees to perform multiple roles, including delivery. To organize limited delivery resources, one shop noted that orders for same-day delivery had to be placed by 12:00 PM; then, a single delivery run was scheduled that afternoon. Of the florists who responded to the survey, $11(10.1 \%)$ indicated making no changes to their delivery system (Table 1).

NEW OR DIFFERENT MERCHANDISE FOR SALE DURING THE COVID-19 PANDEMIC. One retailer remarked that they avoided products that reminded their customers about the virus, but others capitalized on consumer needs by stocking stylish face masks and fragrant antiseptic hand sanitizers [11 respondents (10.1\%)]. Luxury items were featured, such as pamperingtype bath and body products that were sold singly, in gift sets, and as add-on sales with flowers. One shop advertised flower-based cocktail elixirs. Most respondents [73 (67.0\%)] did not offer items they had not normally sold in the past and continued with the design styles and flowers preferred by their clientele (Table 1 ).

Some stores $[3(2.8 \%)]$ indicated decreasing product offerings to accommodate labor and floral inventory reductions. Of those who offered unique products, items that catered to the needs of individuals and families with children having to stay healthy and stay busy while at home were sold. Designers created innovative products beyond arrangements and plants that appealed to do-it-yourself (DIY) consumers during the pandemic; for example, they sold terrarium and floral arrangement kits with instructions. Some offered virtual floral design classes and educational activities suitable for school-aged children. Painting kits and puzzles were also listed in this category (Table 1). Consumers sheltering in place found solace in work-fromhome baskets that featured candles, candies, and notepads, whereas another store created floral and candy gift baskets including a toilet tissue roll in response to the shortage.

RETAIL FLORIST'S TERMINATION OF EMPLOYEES DUE TO THE COVID19 PANDEMIC. When asked "Did you have to terminate any employees due to the COVID-19 pandemic? If so, will all or some of these employees be rehired?" The majority [61 respondents $(56.0 \%)]$ indicated they did not have to fire any employees. Of the 48 $(44.0 \%)$ florists who terminated employees, $26(23.9 \%)$ rehired them or planned to do so and $9(8.3 \%)$ planned to rehire at least some of the terminated staff members; several florists indicated that they might rehire some of their employees but were not sure when or if it would be possible (Table 1). Some florists [3 (2.8\%)] indicated that they would not be hiring back employees who had been terminated during the COVID-19 pandemic. An additional three $(2.8 \%)$ florists made references to employees not returning because they were receiving comparatively higher income from unemployment benefits. Other florists noted that employees chose not to return when asked because of the lingering fears of COVID-19. Other employees were not able to return because of situations changing at home and having to stay with their children (Table 1).

RETAIL FLORISTS' FINANCIAL LOSSES DURING THE COVID-19 PANDEMIC. When asked how much financial loss, if any, their flower shop experienced during the pandemic, 30 respondents $(27.5 \%)$ stated they had not experienced any financial loss because of the pandemic. An additional group of 30 respondents $(27.5 \%)$ claimed financial loss but were not sure of the amount (Table 1). Of those florists who could estimate their shortfalls, 14 (12.8\%) projected losses between $\$ 10,000$ and $\$ 50,000$, and $10(9.2 \%)$ projected losses of more than $\$ 200,000$ because of the COVID-19 pandemic. Of the shops that responded, four (3.7\%) still found a way to increase sales during the pandemic.

OVERALL INNOVATIONS IN RELATION TO TERMINATION RATES AND FINANCIAL Loss. Of the innovations identified by this study, floral shops enacted an average of 3.1 changes/innovations at their shop because of COVID-19, six shops participating in the study chose to make no changes to their business during the pandemic, and two shops enacted seven innovations, which was the most out of any other shop in the study.

Table 2. Cross-tabulation of the overall number of innovations enacted at individual flowers shops because of the COVID19 pandemic and the answers to the question "Did you have to terminate any employees due to the COVID-19 pandemic?" in a study of retail florist novel sales approaches during the COVID-19 pandemic.

\begin{tabular}{|c|c|c|c|c|c|}
\hline \multirow{3}{*}{$\begin{array}{l}\text { Overall innovations } \\
\text { enacted at shop due } \\
\text { to COVID (no.) }\end{array}$} & \multicolumn{2}{|c|}{ Yes } & \multicolumn{2}{|c|}{ No } & \multirow[b]{2}{*}{$P^{\mathrm{z}}$} \\
\hline & (no.) & $(\%)$ & (no.) & $(\%)$ & \\
\hline & \multicolumn{4}{|c|}{ Did you have to terminate any employees due to the COVID-19 pandemic? } & 0.380 \\
\hline 0 & 1 & 2.1 & 5 & 8.2 & \\
\hline 1 & 5 & 10.4 & 11 & 18.0 & \\
\hline 2 & 8 & 16.7 & 8 & 13.1 & \\
\hline 5 & 8 & 16.7 & 5 & 8.2 & \\
\hline 6 & 3 & 6.3 & 3 & 4.9 & \\
\hline 7 & 2 & 4.2 & 0 & 0.0 & \\
\hline Total & 47 & 43.1 & 56 & 51.3 & \\
\hline
\end{tabular}

${ }^{\mathrm{z}}$ Significant at $P<0.05$. 
Table 3. Cross-tabulation of the overall number of innovations enacted at individual flowers shops because of the COVID19 pandemic and the answers to the question "Did your flower shop undergo financial losses during the COVID-19 pandemic?" in a study of retail florist novel sales approaches during the COVID-19 pandemic.

\begin{tabular}{|c|c|c|c|c|c|c|c|c|c|}
\hline \multirow{3}{*}{$\begin{array}{l}\text { Overall innovations } \\
\text { enacted at the shop } \\
\text { because of COVID-19 } \\
\text { (no.) }\end{array}$} & \multicolumn{2}{|c|}{ Yes } & \multicolumn{2}{|c|}{ No } & \multicolumn{2}{|c|}{ Financial gain } & \multicolumn{2}{|c|}{ Not sure } & \multirow[b]{2}{*}{$P^{\mathrm{z}}$} \\
\hline & (no.) & $(\%)$ & (no.) & $(\%)$ & (no.) & $(\%)$ & (no.) & $(\%)$ & \\
\hline & \multicolumn{8}{|c|}{ Did your flower shop undergo financial losses during the COVID-19 pandemic? } & 0.520 \\
\hline 1 & 6 & 13.3 & 5 & 16.7 & 0 & 0.0 & 5 & 16.7 & \\
\hline 2 & 5 & 11.1 & 5 & 16.7 & 1 & 25.0 & 5 & 16.7 & \\
\hline 5 & 2 & 4.4 & 6 & 20.0 & 0 & 0.0 & 5 & 16.7 & \\
\hline 6 & 2 & 4.4 & 2 & 6.7 & 0 & 0.0 & 2 & 6.7 & \\
\hline 7 & 2 & 4.4 & 0 & 0.0 & 0 & 0.0 & 0 & 0.0 & \\
\hline Total & 42 & 38.5 & 30 & 27.5 & 3 & 2.7 & 28 & 25.6 & \\
\hline
\end{tabular}

${ }^{\mathrm{z}}$ Significant at $P<0.05$.

Overall innovations enacted at an individual flower shop were cross-tabulated with the questions "Did you have to terminate any employees due to the COVID-19 pandemic?" and "Did your flower shop undergo financial losses during the COVID-19 pandemic?" to identify relationships between variables. A chi-square test was performed to test the statistical significance of the cross-tabulations.

It was found that when asked "Did you have to terminate any employees due to the COVID-19 pandemic?", the flower shops that answered "no" [56 (51.3\%)] collectively enacted more innovations than those shops that answered "yes" [47 $(43.1 \%)]$, although no significant difference was found between these groups $[P=0.380$ (Table 2$)]$. No significant differences were found when the numbers of innovations enacted by a shop were compared with the answers to the question "Did your flower shop undergo financial losses during the COVID-19 pandemic?" $[P=0.520$ (Table 3)].

\section{Conclusions}

The COVID-19 pandemic has been a challenging time for most small businesses and retail flower shops that specialize in value-added flowers because gifts have not been spared. Findings of this study support the conclusions of past research that analyzed the 1918 pandemic. As in 1918, during the COVID-19 pandemic, hours of work decreased sharply because of the fear of illness and mandated government lockdowns. Floral retail shops experienced a decline in retail sales because of cancellations of leisure activities and large events, just as in 1918 (Turner and Akinremi, 2020). Although at the onset of the COVID-19 pandemic less than half of florists in the United States thought they could weather the pandemic with a profitable Mother's Day, most florists felt they could sustain their business by September (Westbrook, 2020c). Consumer interests in flowers and their emotional messages resulted in the continuation of sending expressive floral gifts to family and friends. The positive communication value of flowers and plants maintained the retail flower business for retail florists who enacted safe and effective transactions and deliveries.

Much of a retail flower shop's revenue throughout the year relies on the social gathering of people in complementary industries, such as the wedding and funeral industries. In the absence of these events, florists who rely on these occasions had to restructure their business models to accommodate scaled-down social gatherings to stay solvent. Event florists developed petite wedding flower packages to target couples who elected intimate pandemic weddings instead of pausing for a potential series of postponed affairs.

Many florists relied on social media to spread the word to customers that they were still open while simultaneously modifying their websites to accurately reflect products in stock during the pandemic. They advertised on-hand merchandise and reached deeper into the existing inventory, sharing digital images of in-stock containers and other merchandise. Through social media, they were able to explain the convenience and safety of contact-free ordering and delivery, and they marketed products to satisfy psychological needs.

Because of the global supply chain disruption in the flower market, consistent reliability of flowers in parts of the country was interrupted, thus causing some florists to seek out local flower farms and market "designer choice" arrangements from their shops. The search for flowers enabled retailers to locate diverse sources of products, which was a healthy addition to the buyer's market.

Florists attempted to work around restrictions intended to reduce the spread of the virus by creating DIY design kits and selling self-care baskets and family entertainment gifts such as puzzles. Some florists created novelty designs based on pandemic news. Because of either city government ordinances or personal concerns, many of the flower shops that responded to the survey enacted contactless delivery and pick-up systems. These florists described effects on their businesses that aligned with those of past pandemics (Turner and Akinremi, 2020). This study documented the responses of retail florists to the COVID19 pandemic, and it can serve as a reference for those businesses to formulate a response to future pandemics.

\section{Literature cited}

Allen, J., S. Almukhtar, A. Aufrichtig, A. Barnard, M. Bloch, S. Cahalan, W. Cai, J. Calderone, K. Collins, M. Conlen, L. Cook, G. Gianordoli, A. Harmon, R. Harris, A. Hassan, J. Huang, D. Issawi, D. Ivory, K. Lai, A. Lemonides, E. Lutz, A. McCann, R. Oppel, Jr., L. Patel, A. Saldanha, K. Semple, S. Seroussi, J. Shaver, A. Singhvi, C. Smart, M. Smith, A. Sun, R. 
Taylor, D. Watkins, T. Williams, J. Wu, and K. Yourish. 2021a. Brazil coronavirus map and case count. 20 Mar. 2021. <https:// www.nytimes.com/interactive/2020/ world/americas/brazil-coronavirus-cases. html $>$.

Allen, J., S. Almukhtar, A. Aufrichtig, A. Barnard, M. Bloch, S. Cahalan, W. Cai, J. Calderone, K. Collins, M. Conlen, L. Cook, G. Gianordoli, A. Harmon, R. Harris, A. Hassan, J. Huang, D. Issawi, D. Ivory, K. Lai, A. Lemonides, E. Lutz, A. McCann, R. Oppel, Jr., L. Patel, A. Saldanha, K. Semple, S. Seroussi, J. Shaver, A. Singhvi, C. Smart, M. Smith, A. Sun, R. Taylor, D. Watkins, T. Williams, J. Wu, and K. Yourish. 2021b. Corona virus in the U.S.: Latest map and case count. 20 Mar. 2021. <https:// www.nytimes.com/interactive/2020/us/ coronavirus-us-cases.html $>$.

Anacleto, A., S. Luciane, and A.P. AraujoBornancin. 2020. Between flowers and fears: The new coronavirus pandemic (COVID-19) and the flower retail trade. Ornam. Hort. 27:26-32, https://doi. org/10.1590/2447-536X.v27il.2232.

Bartik, A., M. Bertrand, Z. Cullen, E. Glaeser, M. Lica, and C. Stanton. 2020. The impact of COVID-19 on small business outcomes and expectations. Small Business 117:17657-17666, https://doi. org/10.1073/pnas.2006991117.

Business Brokerage Press. 2020. Sample BRG entry: Florists. 20 Mar. 2021. <https:// businessbrokeragepress.com/2012/09/ sample-brg-entry-flower-shops-florists $/>$.

Etheredge, C.L. and T.M. Waliczek. 2020. Perceptions of environmental health and willingness to compost fresh cut floral waste by retail flower shop owners. Hort-
Technology 30:751-760, https://doi. org/10.21273/HORTTECH04724-20.

Faux, Z., D. Herbling, and R. Munsterman. 2020 . The crash of the $\$ 8.5$ billion global flower trade. 20 Mar. 2021. <https:// www.bloomberg.com/features/2020flower-industry-crash $/>$.

Kakissisk, J. 2020. The Netherlands' huge flower sector wilts as coronavirus hurts business. 20 Mar. 2021. < https://www. npr.org/2020/03/25/820239298/ netherlands-huge-flower-sector-wilts-ascoronavirus-hurts-business $>$.

McFarland, A.L., T.M. Waliczek, C.L. Etheredge, and J.M. Sommerfeld-Lillard. 2018. Understanding motivations for gardening using a qualitative general inductive approach. HortTechnology 28:289-295, https://doi.org/10.21273/HORTTECH 03972-18.

Mertens, G., G. Lotte, S. Duijndam, E. Salemink, and I.M. Engelhard. 2020. Fear of the coronavirus (COVID-19): Predictors in an online study conducted in Mar. 2020. J. Anxiety Disord. 74:1-8, https:// doi.org/10.1016/j.janxdis.2020.102258.

Solly, M. 2020. What we can learn from the 1918 influenza diaries. 20 Mar. 2021. <https://www.smithsonianmag.com/ history/what-we-can-learn-1918-influenzadiaries-180974614/>.

Taubenberger, J.K. and D.M. Morens. 2006. 1918 influenza: The mother of all pandemics. Emerg. Infect. Dis. 12:15-22. $<$ https://wwwnc.cdc.gov/eid/article/12/ 1/05-0979_article $>$.

Turner, J. and T. Akinremi. 2020. The business effects of pandemics - A rapid literature review. 20 Mar. 2021. <https:// www.enterpriseresearch.ac.uk/wp-content/ uploads/2020/04/ERC-Insight-Thebusiness-effects-of-pandemics- $\%$ E $2 \% 80 \%$ 93-a-rapid-literature-review-Final.pdf $>$.

U.S. Department of Agriculture. 2021. Plants database. 21 July 2020. <https:// plants.sc.egov.usda.gov/java/nameSearch $>$.

U.S. Small Business Administration. 2020. Size standards. 21 July 2021. <https:// www.sba.gov/federal-contracting/ contracting-guide/size-standards $>$.

Westbrook, M. 2020a. Buoyed by Easter, most surveyed retailers will open on Mother's Day. 20 July 2020. <https://safnow. org/2020/04/22/buoyed-by-easter-mostsurveyed-retailers-will-open-on-mothersday $/>$.

Westbrook, M. 2020b. 70 Percent report Mother's Day sales increases. 20 July 2020. <https://safnow.org/2020/05/20/70percent-report-mothers-day-salesincreases $/>$.

Westbrook, M. 2020c. 73 Percent of SAF survey respondents confident they'll make it through crisis. 20 July 2020 . <https:// safnow.org/2020/09/02/73-percentrespondents-confident-through-crisis $/>$.

World Health Organization. 2020. WHO director-general's opening remarks at the media briefing on COVID-19. 20 July 2020. <https://www.who.int/directorgeneral/speeches/detail/who-directorgeneral-s-opening-remarks-at-the-mediabriefing-on-covid-19-11-march-2020>.

Wright, B. 2020. The problem right now is demand: Growers, importers talk supply chain strain. 20 July 2020. <https:// safnow.org/2020/03/25/growersimporters-talk-supply-chain-strain/>. 